Associate Professor for the Department of General and Socio-Economic Disciplines, Educational and Scientific Technological Institute of State University of Economics and Technologies.

Circle of scientific interests: technology and methodology of teaching humanities in higher education institutions.

BRATANYCH Olha Hryhorivna - Candidate of Pedagogical Sciences, Associate Professor, Associate Professor for the Department of General and
Socio-Economic Disciplines, Educational and Scientific Technological Institute of State University of Economics and Technologies.

Circle of scientific interests: learning theory; competency based approach to teaching English for specific purposes (ESP) in a technical university.

Стаття надійшла до редакиії 18.03.2021 р.

UDC 378.147

DOI: $10.36550 / 2415-7988-2021-1-194-84-88$

GALETSKYI Sergii Mykolaiovych $\mathrm{PhD}$ in Pedagogy, Assistant Professor Department of Business Communication The National University of Ostroh Academy ORCID:https://orcid.org/0000-0001-6532-3108 e-mail: sergii.galetskyi@oa.edu.ua

\title{
E-LEARNING AS A LEADING COMPONENT OF INFORMATION AND COMMUNICATION TECHNOLOGIES IN THE EDUCATIONAL PROCESS
}

\begin{abstract}
Statement and substantiation of the relevance of the problem. The last two decades have been marked by a significant increase in the emphasis on teaching on the basis of information and computer technology. A withdrawal from traditional training was based on the rapid development of the Internet. It has provided users with online communication, as well as sharing, storing and disclosing large amounts of data. The use of information and communication technologies in education makes it possible to increase its efficiency and accessibility. Many universities are actively developing a range of technologies, including mixed learning, with the aim of implementing E-learning at the university.

In all historical epochs, education played an important role in a society. Question of philosophical understanding of goals, values, place and role of education in the areas of public life have always been relevant. They have not lost their relevance in our time, vice versa - have acquired a qualitatively new meaning. In the conditions of dynamic and ambitious socioeconomic transformation of Ukrainian society education becomes the object of new growing requirements of the individual, society and state. These requirements are a major factor of the driving force behind the development of the education system.

The dominant trend of the modern world, and particularly Ukrainian society, is increasing its widespread computerization and information and communication technologies. A high level of modern technology and electronics, the increasing amount of information are necessary for solving everyday professional tasks for every member of society.
\end{abstract}

One of the greatest achievements of modern information and computer technology and telecommunications is the opportunity to train without the physical presence of teacher: lesson can be shifted in time (not in accordance with the schedule, but at any other time) and in location (can be not in the classroom but in any other place). These two points can lead to radical changes in education, primarily promote the emergence of new forms of learning.

As Internet use increases within the realm of business communication, marketing, and sales, so does its emphasis in online teaching and learning. As technology impels business and society to be more international, more flexible, and more carefully targeted to specific needs, education must follow. Creating a flexible learning process and an environment that incorporates online technologies can attract more students and improve their access to learning opportunities while enhancing their understanding and retention of new information about both the process and the content of education. Such a learning environment can best target specific and rapidly changing educational needs $[2, \mathrm{p} .11]$.

Analysis of recent research and publications. The basics of using E-learning as a leading component of information and communication technologies in the educational process are currently being developed quite actively in the domestic pedagogical science. Thus, the team of authors (H. Shvachych, V. Tolstoy, L. Petrechuk, YU. Ivashchenko, O. Hulyayeva, O. Sobolenko) analyzes in detail the concepts, advantages and disadvantages of modern ICT and the possibility of their use in the educational process; other scientists have studied 
communication technologies in multiprocessor systems (V. Ivashchenko, YE. Bashkov, H. Shvachych, M. Tkach). M. Kuz'mina, T. Pivovarova ta M. Chuprakov study cloud technologies in modern media education; a team of Dnipropetrovsk scientists is actively studying adaptive online learning with the help of modern (N. Lysovenko, I. Byelova, V. Viktorov).

The purpose of the article is to analyze the role and importance of E-learning as an element of ICT in the educational process in the context of the formation of an information society.

The main material of the study. The evolution of E-learning. Distance education has gone through the way from the form of using primarily printed materials, to the global movement using the latest computer technology and media. The first invention that allowed moving the learning process in time and space was, of course, the book. It has been using as a teaching tool for many years and still remains extremely popular nowadays. The book is the main source of academic information, but another mandatory component of training, in addition to information, is a communication between teacher and student. With the help of printed or written material between the student and teacher can be arranged defined interaction.

For more than a century, people in different parts of the world take part in the training and receive their education through distance learning. In this system the student receives printed materials, complete writing tasks and send them back to the teacher. After this, he/she receives a feedback in the form of reviews, comments and evaluations. Such training, though is very widespread in the world, has significant limitations for the formation of professional competence of teachers as interaction with the teacher, who conducts the study, is limited to the exchange of written messages. In addition, due to the delay in response from the teacher the quality of learning in distance education system can be insufficient in order to obtain good qualification for the student.

In the early 1980 s, the main objectives of the distance education were teaching grant programs that allowed getting a diploma for the students; the fight against illiteracy in developing countries; enable training to economic growth; enriching educational programs in non-traditional educational institutions. New technologies, globalization and new ideas for teaching students with new types of the textbooks and new types of electronic training materials (computer, multimedia projector and sensor/smart boards) set challenges to traditional approaches in the practice of distance education.

Today innovations, which are typical for any professional activity of human being, become the subject of study, analysis and implementation. Innovations do not occur alone, they are definitely the result of scientific research, advanced teaching experience of individual teachers and entire groups. This process is not spontaneous and it needs perfect management.

One type of innovation in the vocational education nowadays is the implementing/usage of E-learning. In recent decades, rapidly developing scientific and methodical bases of E-learning took place. The main ways to improve the efficiency of learning while using information technologies, pedagogical approaches to the computerization of the educational process, didactic features of computer tools are investigated now.

New challenges to the qualification of the working force in information society and Elearning. Nowadays the qualified workers need to know how to dynamically adapt to the rapid updating of knowledge and technology and they must constantly improve their professional competence. They need to know how to replenish their professional knowledge during a short period of time. At the same time, to support technology up to date and therefore to have successful technological development of the country it is necessary to increase the share of highly qualified specialists with higher education. Otherwise, in the foreseeable future society will be unable to manage those production technologies, which were «generated» by this society. In order to manage the whole process effectively a person needs to understand this process fully.

Today in the whole world processes of transition to an information society actively take place. Ukraine is no an exception one. Participation of our country in the transcontinental computer information systems has long been a necessity. Unfortunately, the process of transition is not as fast as we really want. I am more than convinced that at least a large part of the population of Ukraine never seen a computer, not even to talk about the ability to use it. A limited number of teachers using the Internet in order to prepare for classes and therefore get some information on the rational use of the «web» is extremely difficult. However, of course, the largest source of information is covered in the Internet itself. You can find programs that will be useful in preparing for the sessions, but it requires Internet connection in educational institutions.

In Ukraine, the task of implementing Elearning in education was initiated in 1995 in the Program on Informatization of Ukraine. It is expected that, while analyzing the promising potential of E-learning, this form of education will be one of the most popular in the XXI 
century. Ukraine, as a state, is actively working on this problem right now.

In healthy online learning community, there is intellectual trust among participants and the facilitator. Evidence of this trust show up in participants' apparent willingness to take intellectual risks, and to make corrections where needed so that no one is misinformed [3, p. 80].

Cheering the fact that the number of computer users every day increases exponentially. Creation of telecommunication infrastructure, provision of educational institutions with computers, the introduction of mass education programs are an integral part of the implementation of the national program of informatization of educational process.

With the rapid development of technology, distance education while using a variety of telecommunications is intended to meet the educational needs of the growing population. Despite how distance education is implemented in different countries, there are their own peculiarities of its use at the level of secondary and higher education. These training programs are especially useful for many people who, due to financial, physical or geographical circumstances, are unable to get traditional education. Thus, distance learning provides equal access to the quality of education.

From stepchild to wunderkind, technology that spawned the Internet has moved distance learning to the forefront of educational innovation in the 21 st. century. Sensing an opportunity to reach more students and supplement flagging tuition revenues, major educational institutions have proceeded to expand their mission to include activities in online education [7, p. 3].

Some aspects of the implementation of $E$ learning in the university. E-learning, according to some scientists, is one of the leading components of modern society and one of the main forms of education. The main reasons that encourage people to study in E-learning system are:

1) People, who wish to obtain a degree in any field or get training for a certain profession, for some reason cannot regularly attend the classes, or school is far from their place of residence, or they cannot attend school due to health matters;

2) People want to study in their own way. They choose subject, courses, training materials, methods of teaching, time and pace of learning;

3) A person needs to have an access to the many and varied sources of information such as libraries, data banks, educational institutions and teachers/experts in a particular field of study.

Today there is no consensus among scientists on the definition of «E-learning». There are options such as «distant education», «distant learning». Some foreign researchers, placing special role of telecommunications in distance education, defining it as «teletraining». However, in the scientific world most often scientists use the term «E-learning».

First of all, we should note the basic principles of E-learning: continuity; openness; flexibility; efficiency; humanization; equality of opportunity; self-identity. These principles allow seeing the real image of perspective education.

In the structure of E-learning in educational establishments it is necessary to have such elements:

1) E-learning system environment with the necessary means for communication of participants of E-learning;

2) electronic database of educational material;

3) virtual laboratory;

4) E-learning participants (teachers, students) and technicians (programmers, system administrators, web designers, animators).

An access to the Internet in the educational process is a new opportunities for both teachers and students. Internet in universities can be used not only to obtain information from reputable sources worldwide, but also for distance education, conduct Internet - competitions, conferences and seminars. Internet facilitates contacts between people and organizations, wherever they are.

Good online learning requires considerable preparation. Just like education in the classroom, it begins with content, without which there would be no learning. Then, technology enters the picture and rearranges the elements in ways that make E-learning considerably different from the classroom. The design of the course, the way that it goes onto the web, the manner in which students access and interact with the content - all affect outcomes [5, p. 39].

Among the varieties of modern information and communication technologies, multimedia technologies and teaching aids are perhaps the most popular today. Multimedia technologies are often defined as a means of integrated interaction of audio and visual effects using modern ICT, which can integrate text, sound, graphics, shooting, playback, etc. in the learning process. Teaching aids traditionally include: computerbased testing systems for students; educational dialogue systems; computer simulators that simulate the professional activities of specialists; databases of different types and levels; electronic textbooks; virtual laboratories and others.

Multimedia support of the process of formation of communicative competence of future teachers of foreign languages is based, as a rule, on the use of several elements of the 
multimedia complex:

1) interactive display, the size of which is determined by the number of students in the classroom;

2) interactive whiteboard with appropriate equipment;

3) necessary accompanying devices (teacher's computer, various student gadgets, Internet connections, webcams, adapters, etc.).

All these components of multimedia support of the process of formation of communicative competence of future teachers of foreign languages can be combined with the cloud environment of this area of training, developed and implemented in a particular institution of higher education. Unfortunately, foreign language faculties (institutes) most often use separate components of information and communication technologies to form students' communicative competence, often without linking them into a system of interdependent elements. Thus, most often the electronic textbook is not used in the process of direct teaching of foreign languages, and interactive whiteboards and displays are not connected to the cloud environment.

In this regard, the urgent task is to develop and implement a system of ICT tools and methods of their use, which would maximize the advantages and minimize the disadvantages of these technologies in the process of forming the communicative competence of future foreign language teachers.

E-learning as a method for increasing motivation and self-study skills. Besides, analyzing the current stage of development of education can distinguish the distinctive feature that characterizes today's students: young people do not want to study or study carelessly, thinking that money can be earned without higher education, but in general, many young people have high motivation for learning, caused by the need to have a high level of life.

E-Learning supports self-directed types of learning. High motivation and self-study skills are prerequisites and must be complemented by an appropriately structured didactic learning environment. Self-organization and selfresponsibility are important skills within flexible working and learning cultures. The use of eLearning systems requires (and promotes) to a higher degree [4, p. 157]. This implies an important condition for E-learning: in the E- learning system can learn only highly motivated, focused and organized persons. Of course, this condition we can hardly consider as a restriction on the use of E-learning, as any form of training requires these qualities.

The online class is available for 24 hours 7 days a week. In this way, when you or your students have a good idea or generally feel inspired, you know the class is available and receptive. We might not necessarily feel our best at scheduled time that a class meets on campus, but online we can join our class with a flick of a switch, as soon as we have an inspiration, thereby grabbing the idea while it is fresh and exciting [1, p. 65]. With the advent of multimedia learning tools that have very high technical and didactic capabilities, were developed a number of multimedia programs, courses, electronic textbooks, encyclopedias, guidebooks and other electronic documents. Computer manuals should belong (according to the functions they perform) to the mandatory components of the educationalmethodical complex but due to some objective reasons they still belong to the optional components of the educational-methodical complex.

E-learning as a way to improve an access to education. Through the use of new information technologies and the Internet have eliminated national borders. The knowledge gradually migrates from the bookshelves in local libraries and computers in the classrooms to the worldwide network, where they become available for public and can be obtained without interference from anywhere in the world. Thanks to electronic education technologies will gradually fade boundaries of specific schools, promoting their mutual integration, expanding opportunities to provide educational services, providing open education.

The right to education is one of major human rights in a civilized society. Without proper education a person is unable to perceive themselves as part of society as a free figure, not even to be able to understand the essence of those rights and freedoms guaranteed by the Constitution. Education is an important factor of socialization.

In addition, distance education can provide opportunities to get education for people with special needs (disabled), a contingent of special institutions (eg. prison), pensioners, and women raising young children and so on. Online can be an open door for those with restricted mobility or difficulty in accessing buildings. Online provides an opportunity to "travel", meet and learn with others with comparative ease, but only if accessible materials and processes are on offer. Technology can help or hinder, of course. Keyboard or speech commands can be provided for those unable to use a mouse [8, p. 115]. As a result of this process, new positive changes take place in the everyday life of a human being, person becomes opened for the new experiences and enriches inner spiritual world.

Conclusions and prospects for further researches of directions. Summarizing 
everything said above, we can say that Elearning is one of a progressive form of learning and serves as a key element that improves the professional level of a student. The implementation of the E-learning in the scientific establishments provides perfect (compared with other forms of training) speed of refreshing the knowledge rate, supported by information resources, selected by the students from the world's electronic information networks. Educational use of information technologies provide significant empowerment of individualization and differentiation of learning. Development and implementation of the new elements of the E- learning in the preparation of future professionals is one of the main goals for further studies.

\section{СПИСОК ДЖЕРЕЛ}

1. Bender T. Discussion - based online teaching to enhance student learning. USA: Stylus. 2003. 206 p.

2. Brown D. G. Developing faculty to use technology. Programs and strategies to enhance teaching. USA: Wiley. 2010. 337 p.

3. Collison G., Elbaum B., Haavind S., Tinker R. Facilitating online learning. Effectve strategies for. USA: Atwood Publishing. 2000. 215 p.

4. Grimus M. eLearning, eTeaching, eEducation. An aspect of a new learning culture. Brno-Vienna. 2003. $153 \mathrm{p}$.

5. Maeroff G. I. A Classroom of One. How Online learning is changing our schools and colleges. USA: Palgrave Macmillan. 2003. 309 p.

6. Романов А. Н., Григорович Д. Б. Технология системы дистанционного обучения в экономическом образовании. М.: ЮНИТИ-ДАНА. 2000. $303 \mathrm{c}$.

7. Rudestam K. E., Schoenholtz J. Handbook of online learning. Innovations in Higher Education and corporate training. USA: Sage Publications. 2002. $400 \mathrm{p}$.

8. Salmon G. E-moderating: the Key to Teaching and learning Online. Great Britain: Routledge Falmer. 2008. 288 p.

\section{REFERENCES}

1. Bender, T. (2003). Dyskusiyne vykladannya v Interneti dlya pokrashchennya navchannya studentiv. USA: Stylus. [Discussion - based online teaching to enhance student learning].

2. Brown, D. G. (2010). Rozvytok fakul'tetu dlya vykorystannya tekhnolohiy. Prohramy ta stratehiyi dlya vdoskonalennya vykladannya. USA: Wiley.
[Developing faculty to use technology. Programs and strategies to enhance teaching].

3. Collison, G., Elbaum, B., Haavind, S., Tinker, R. (2000). Spryyannya navchannyu $v$ Interneti. Efektyvni stratehiyi. USA: Atwood Publishing. [Facilitating online learning. Effectve strategies].

4. Grimus, M. (2003). E-navchannya, Evykladannya, E-osvita. Aspekt novoyi kul'tury navchannya. Brno-Vienna. [eLearning, eTeaching, eEducation. An aspect of a new learning culture].

5. Maeroff, G. I. (2003). Klasna kimnata dlya odnoho. Yak onlayn-navchannya zminyuye nashi shkoly ta koledzhi. USA: Palgrave Macmillan. [A Classroom of One. How Online learning is changing our schools and colleges].

6. Romanov, A., Hryhorovych, D. (2000). Tekhnologiya sistemy distantsionnogo obucheniya $v$ ekonomicheskom obrazovanii. [Remote learning system in the Economic Education]. Moscow.

7. Rudestam, K. E., Schoenholtz, J. (2002). Dovidnyk z onlayn-navchannya. Innovatsiyi u vyshchiy osviti ta korporatyvnomu navchanni. USA: Sage Publications. [Handbook of online learning. Innovations in Higher Education and corporate training].

8. Salmon, G. (2008). Elektronne moderuvannya: klyuch do vykladannya ta navchannya $v$ Interneti. Great Britain: Routledge Falmer. [E-moderating: the Key to Teaching and learning Online].

\section{ВІДОМОСТІ ПРО АВТОРА}

ГАЛЕЦЬКИЙ Сергій Миколайович кандидат педагогічних наук, старший викладач кафедри міжнародної мовної комунікації Національного університету «Острозька академія».

Наукові інтереси: комп'ютерні технології в освіті, дистанційне навчання, формування професійної компетентності викладачів іноземних мов.

INFORMATION ABOUT THE AUTHOR

GALETSKYI Sergii Mykolaiovych - Assistant Professor of the Department of International Language Communication, Candidate of Pedagogical Sciences ( $\mathrm{PhD}$ in Pedagogy), National University «Ostroh Academy».

Circle of scientific interests: computer technologies in education, distance learning, formation of professional competence of foreign language teachers.

Стаття надійшла до редакиії 26.04.2021 р. 